\title{
Archaeological Investigations at the Gresser House (41BX369) San Antonio, Texas
}

James E. Ivey

Follow this and additional works at: https://scholarworks.sfasu.edu/ita

Part of the American Material Culture Commons, Archaeological Anthropology Commons, Environmental Studies Commons, Other American Studies Commons, Other Arts and Humanities Commons, Other History of Art, Architecture, and Archaeology Commons, and the United States History Commons

Tell us how this article helped you.

This Article is brought to you for free and open access by the Center for Regional Heritage Research at SFA ScholarWorks. It has been accepted for inclusion in Index of Texas Archaeology: Open Access Gray Literature from the Lone Star State by an authorized editor of SFA ScholarWorks. For more information, please contact cdsscholarworks@sfasu.edu. 


\section{Archaeological Investigations at the Gresser House (41BX369) San Antonio, Texas}

\section{Creative Commons License}

(c) (1) (8)

This work is licensed under a Creative Commons Attribution-NonCommercial 4.0 International License 


\section{ARCHAEOLOGICAL INVESTIGATIONS AT THE GRESSER HOUSE (41 BX 369) San Antonio, Texas}

James E. Ivey

Center for Archaeological Research

The University of Texas at San Antonio Archaeological Survey Report, No. 60

1978 
ARCHAEOLOGICAL INVESTIGATIONS AT THE

GRESSER HOUSE (41 BX 369)

SAN ANTONIO, TEXAS

James E. Ivey

Center for Archaeological Research The University of Texas at San Antonio

Archaeological Survey Report, No. 60 
List of Figures and Tables. ................ . . . . . i

Acknowledgments . . . . . . . . . . . . . . . . i i i

Introduction. ..................... . . T

Historical Background . . . . . . . . . . . . . . . . 1

Preliminary Investigations. . . . . . . . . . . . . 5

The Excavations..................... 8

The Artifacts . . . . . . . . . . . . . . . . . . 9

Preliminary Investigations ................ 9

Test Pit 1; Stratum 1................ 16

Test Pit 2; Stratum 1. ................ 17

Test Pit 2; Stratum 2. . . . . . . . . . . . 18

Test Pit 3; Stratum 1. . . . . . . . . . . . 18

Test Pjt 3; Stratum 2. . . . . . . . . . . . . 19

Test Pit 4; Stratum 2. . . . . . . . . . . . . 20

Artifacts from Construction Trenches . . . . . . . . . 20

Artifacts of Unknown Provenience . . . . . . . . . . . 22

Artifact Dating . . . . . . . . . . . . . . . . 24

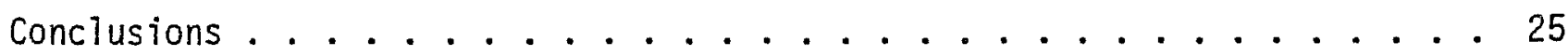

Recommendations ................... . . 29

References Cited. . . . . . . . . . . . . . . . . 37 


\section{LIST OF FIGURES AND TABLES}

Figure

Page

1. Location of Gresser House. . . . . . . . . . . . . 2

2. La Villita, Western Section. .............. 3

3. The Gresser House. . . . . . . . . . . . . . 6

4. South Wall of Construction Trench. ............ 7

5. Views of Excavations .................. 10

6. Ceramic Artifacts. . . . . . . . . . . . . 11

7. Metal Artifacts. .................. 13

8. The Gresser House. . . . . . . . . . . . . . . 28

Table

1. Gresser House Artifacts and Provenience. . . . . . . . . . 14 


\section{ACKNOWLEDGMENTS}

I would like to thank Barbara Luckett for her advice and for the use of the extensive files dealing with the early days of San Antonio, and the San Antonio Conservation Society for the use of their extensive library. I would also like to acknowledge my debt to the writings of Judy Varga, on file at the SACS Library. It was she who first advanced the idea that Jack Hays' house was on the north portion of New City Block 134, based on her extensive research. 


\section{INTRODUCTION}

During March 1977, archaeologists from the Center for Archaeological Research, The University of Texas at San Antonio, conducted archaeological investigations at the historic Gresser House located on the northwest corner at the intersection of South Presa and Nueva Streets in the historic district of downtown San Antonio (Fig. 1).

The investigations were designed to examine building foundation remains which were uncovered during renovation work being carried out at the Gresser House. These were continued investigations following recommendations made by Anne Fox, who did an initial examination of structural remains and associated animal bones and artifacts uncovered by workmen after the removal of a small brick structure attached to the Gresser House.

The archaeological work was done under contract between the Center for Archaeological Research (UTSA) and the San Antonio Conservation Society, Mrs. Barbara G. Luckett, Chairman of Gresser-Hays House, letter dated March 10, 1977.

The field work was done by James E. Ivey, assisted by Lynn Highley, under the general supervision of Dr. Thomas R. Hester, Director, and Mr. Jack D. Eaton, Assistant Director, the Center for Archaeological Research.

The investigations described in this report followed standard archaeological procedures. Soils tested were passed through 1/4-inch mesh screens for retention of artifacts and other diagnostic materials. Collected artifacts were processed in the Center Laboratory and all field and laboratory notes are on file at the Center for Archaeological Research.

\section{HISTORICAL BACKGROUND}

The first non-Indian inhabitants of the area of San Antonio now called La Villita may have been a few families of soldiers assigned to the presidio San Antonio de Bexar when it was established in 1721 (Webb 1952:38; Buckley 1911:55). Later, in 1773, the area was opened for settlement by refugees from the east Texas, Nacogdoches area presidios and missions which had been abandoned (Webb 1952:547). The arrival in 1802 of the Compania Volante from San Carlos de Parras in Chihuahua assigned to occupy the abandoned mission of San Antonio de Valero (the Alamo) added a number of other families to the small village (Fox et al. 1976:6-7); Bexar County Archives [BCA], rol1 31:24,56).

These latest arrivals from Chihuahua probably lived within and around the Alamo; certainly they were recorded as a distinct group, along with their wives and children, in each census of the Compania Volante (BCA, rol1 $35: 561 ; 43: 656$ ). Many of the soldiers of the company stayed on in the Villita area after discharge and established farms, although most had no title to the land on which they lived. It was not until 1818, after the proclamation of the "New Regulations for Presidios" (BCA, Land Grants and Sales [LGS]:93), that many of these squatters and other new settlers began to petition for and receive title to their land in La Villita.

The lot on which the Gresser House stands was originally acquired by petition (Fig. 2). It was actually two lots and the eastern half was granted to the re- 
$\perp \exists \exists Y \perp S \forall S \exists y d$ HLNOS

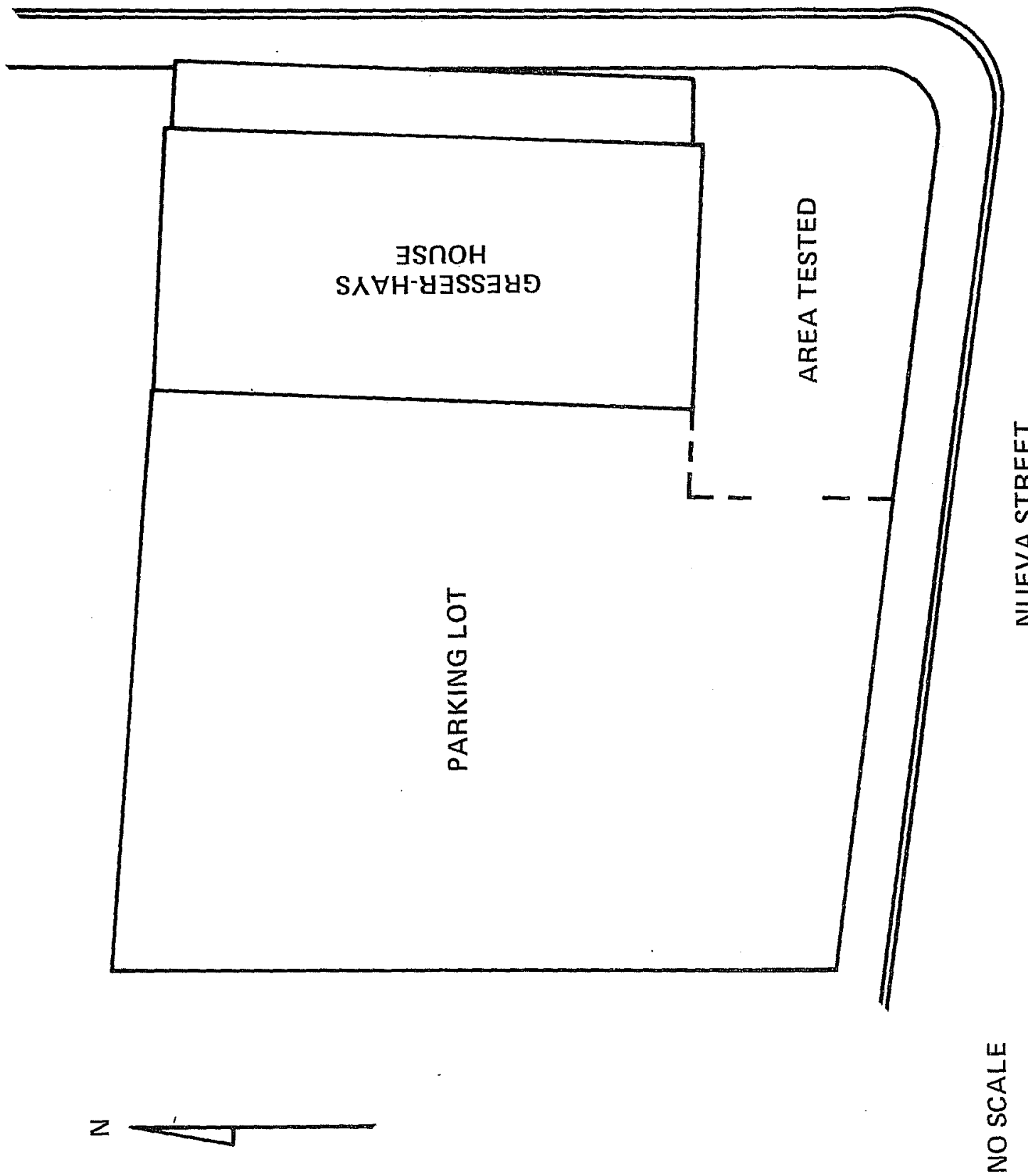




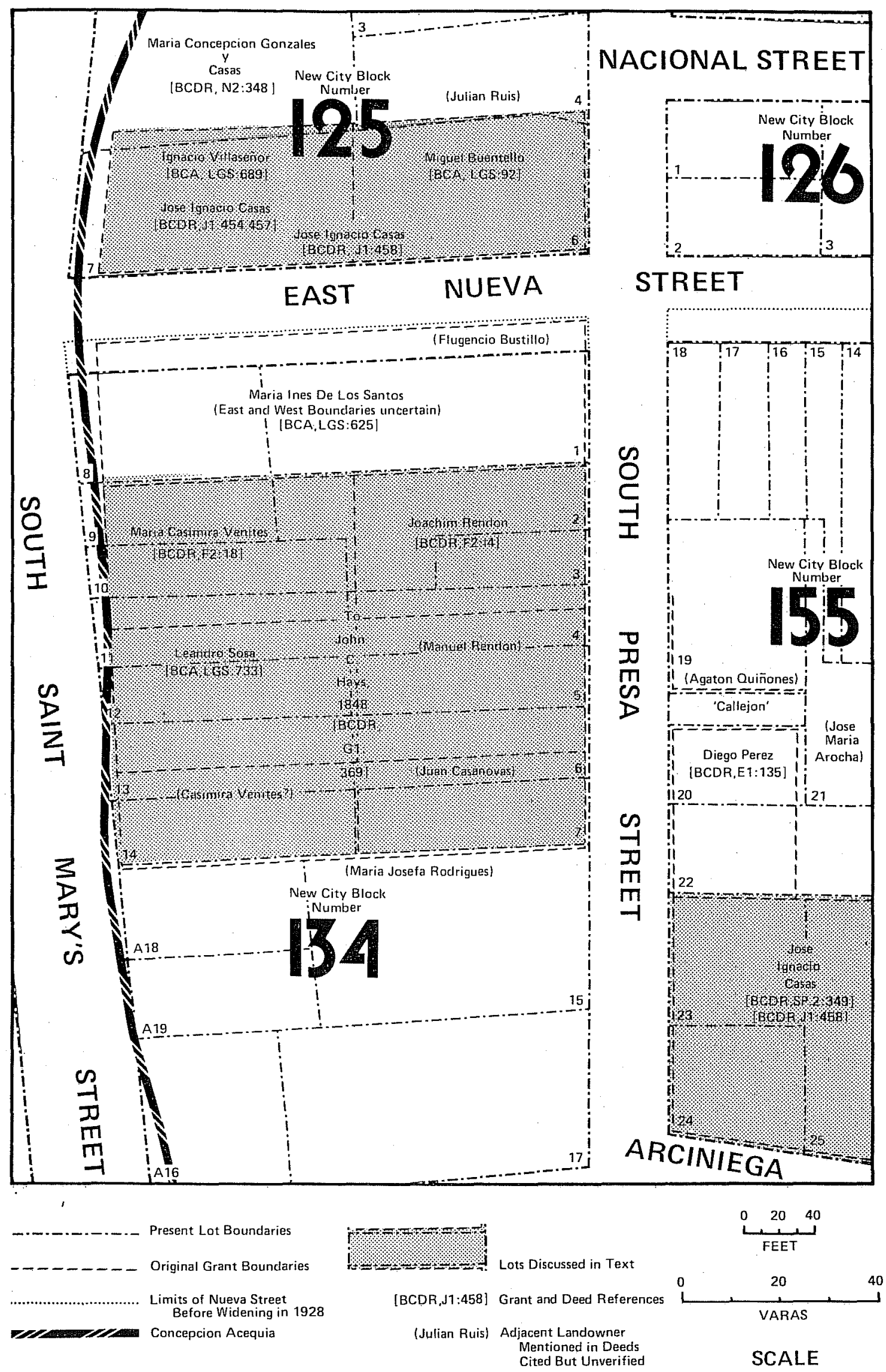

Figure 2. La Villita, Western Section. Shown are the present streets and blocks with the approximate positions of the original land grants and their primary deed references. 
tired soldier Miguel Buentello on February 20, 1818 (BCA, LGS:92). In his petition for the land, dated January 28, 1818, Buentello stated that he had lived in his house on the land since before the death of Governor Manuel de Salcedo in 1813.

The western half of the Gresser lot was granted to a civilian, Ignacio Villaseñor, on February 22, 1818, along with a second lot located near the Alamo. Villaseñor sold both tracts to Jose Ignacio Casas on December 4, 1818 (BCA, LGS:689, Bexar County Deed Records [BCDR], J1:454, 457).

Jose Casas was also a retired soldier and a veteran of the Compania Volante. He was born (around 1758) probably near San Carlos de Parras in Chihuahua and married Maria Concepcion Gonzales, also apparently from the San Carlos area, around 1802. Casas came with the Compania Volante to San Antonio in 1803, and appeared in Bexar records in the first census of the Compania in January 1807 ( $B C A$, roll 35:463). Here he is listed as a common soldier, age 48, with a wife, Concepcion Gonzales, age 27, and two children, ages 2 and 3 . Casas appears again in the Compania census of December 1809 (BCA, roll 43:656), and finally in a list of those members of the Compania who donated to the War Fund in June 1810 (BCA, ro11 45:591).

Casas probably left the Compania around 1811, at the age of 53. Perhaps in preparation for this he petitioned for a grant of land on which to build his house, requesting a lot south of the Alamo (BCDR, Sp.2:402). This document is undated, but a number of details of its content suggest a date of 1810 or 1811 for its preparation. So far as can be told from the records, Casas did not receive the land he requested.

No record of the activities of Casas is known for the period from about 1811 until his purchase of the Villaseñor grant in 1818.

In the summer of 1819 , heavy rains in the San Fernando de Bexar area led to a disastrous flood on July 5 (BCA, LGS:93). Soon after, the owners of the land bordering on the north and south of the Buentello lot petitioned for new lots because their houses had been destroyed in the flood (BCA, LGS:93,581). They were granted the new land for which they petitioned, and apparentiy abandoned their old property.

Jose Casas also petitioned for a new tract of land, on July 10, 1818, but did not mention the flood as the reason for his petition. This may indicate that he had not yet built a house on his lot by mid-1819. He was granted a tract to the southeast of the lot he had bought from Villaseñor, on what is now the northeast corner of South Presa and Arciniega Streets (BCDR, Sp.2:349; Fig. 1). Miguel Buente170 is never mentioned again in the deeds, so far as is known.

Jose Casas died in 1834 or 1835 , at about the age of 76 , a very respectable age for the time (BCDR, E7:135; HR1:144 \#636). His widow, Maria Concepcion Gonzales y Casas, 56 years old, inherited his property and soon thereafter married Justo Esqueda, in September of 1835 (BCDR, HRI:144 \#636). In 1841 her several children by Jose Casas requested a division of his lands, and in July and August of that year the inventory and division were carried out (BCDR, J1:458). By the time of his death, Casas had been the owner of six parcels of land, of which one was a composite made up of the land grants of Villaseñor and Buentello. At some time 
between 1819 and 1841 Casas had acquired the Buentel10 land, but the actual transfer, if there was one, is at present unavailable. It is possible that Buente110, like the land owners to his north and south, abandoned his lot after the flood of 1819, or died in it, and Casas simply added it to his lot soon afterward.

On June 3, 1861, Maria Concepcion Casas sold this lot to Louis Gresser and his wife Celestine Hock Gresser. In the deed, this land and the house on it are described as "the residence of Mirs. Casas and her own private property (BCDR, S2:51)." Louis Gresser deeded al1 rights to the land to his wife on March 25, 1862 (BCDR, S2:253). Celestine Gresser in turn left the property to her daughter Leonie Foutrel on her death in 1915 (Bexar County Probate Minutes [BCPM], \#7996). Leonie Foutrel willed the lot to her son Germain Foutrel on her death in 1940, at which time a store constructed of brick was described as being on the corner of South Presa and Nueva Streets, with a one story stone structure of four rooms on its north (Gresser House), fronting on South Presa (BCPM, \#30342). Germain Foutrel died soon thereafter, and in 1941 the property went to Alta Tschirhart (BCPM, \#4524). Mrs. Tschirhart sold the property to the San Antonio Conservation Society in 1976 (BCDR, 7821:927).

\section{PRELIMINARY INVESTIGATIONS}

On February 25, 1977, during the digging of the foundation trenches for the cinderblock walls dividing the Gresser lot from the sidewalk along South Presa and Nueva Streets (Fig. 3), a quantity of bone was found in the immediate area of the corner of the lot.. Anne A. Fox of the Center for Archaeological Research was called to examine these bone fragments. She found that more bone was still in place in the earth through which the trenches were being dug, along with charcoal, ash and artifacts.

One face of a trench was cleaned and photographed, and a section drawing was made (Fig. 4). Artifacts were collected and their locations noted.

The section drawing (Fig. 4,b) is a composite picture of physical features associated with a series of events which disturbed the earth beneath the Gresser House lot. These features can be considered in approximate chronological order from the right side of the section to the left.

First appearing on the right is an unstratified dark brown earth, apparentiy the same as that into which the foundation trenches of the Casas House (to be discussed below) were dug. No artifacts were found in the soi] of this trench which was examined by Fox. A pit or trench had been dug into this brown soil, its side appearing as the nearly vertical line near the right side of the section drawing. The bottom of this feature apparently extends below the level of the floor of the trench, and so does not appear in the section. In all likelihood the surface through which the feature was dug was above the ground level appearing in the section. It is clear, however, that the feature was more than 1 meter deep and 1.6 meters wide.

This pit or ditch soon began to fill with silt and other material. Included in the fill were artifacts such as bone and ceramic fragments. The fill varied through time, producing a series of layers. Because of the severity of the 


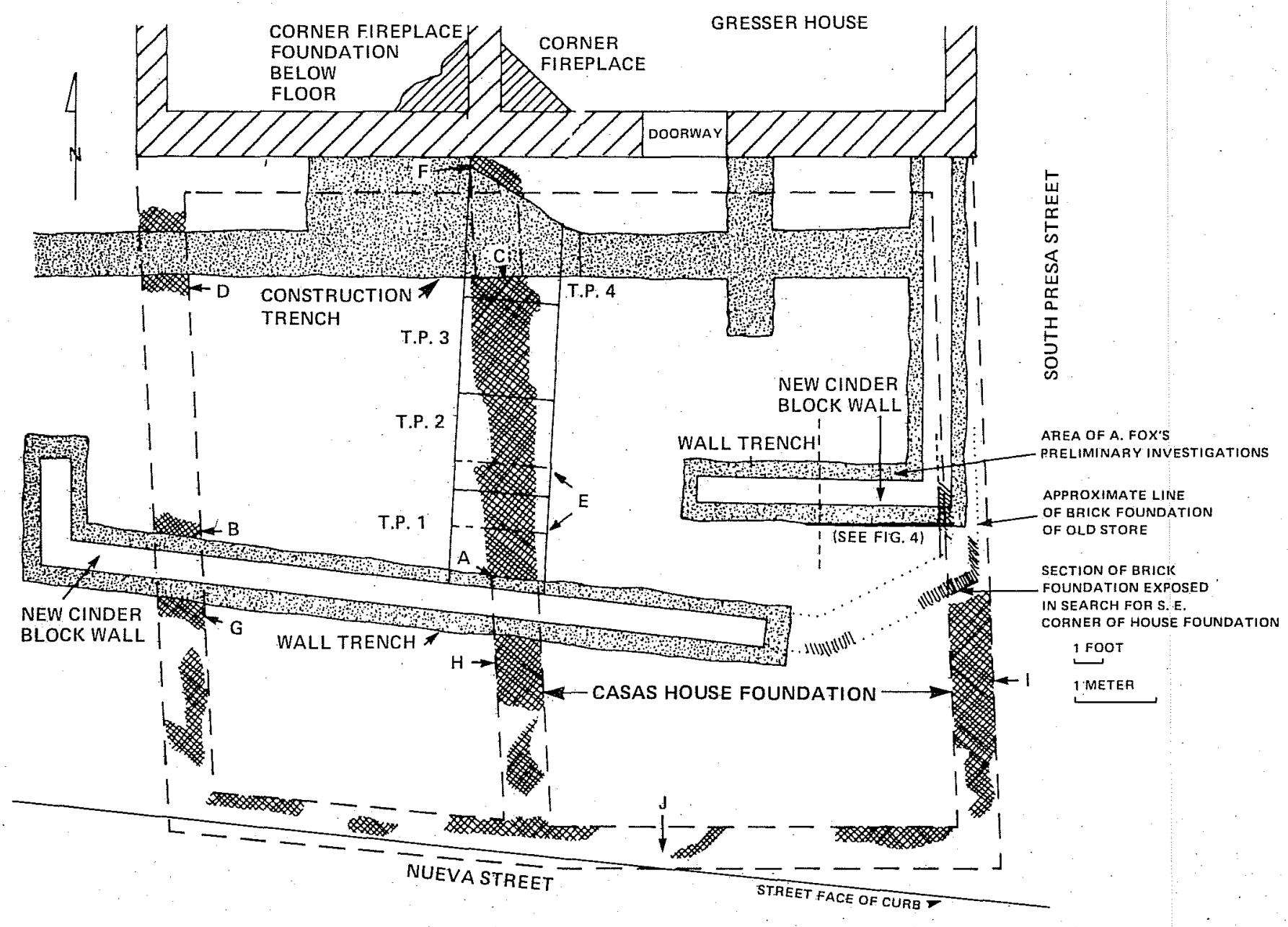

Figure 3. The Gresser House. Areas of construction and archaeological investigation. 


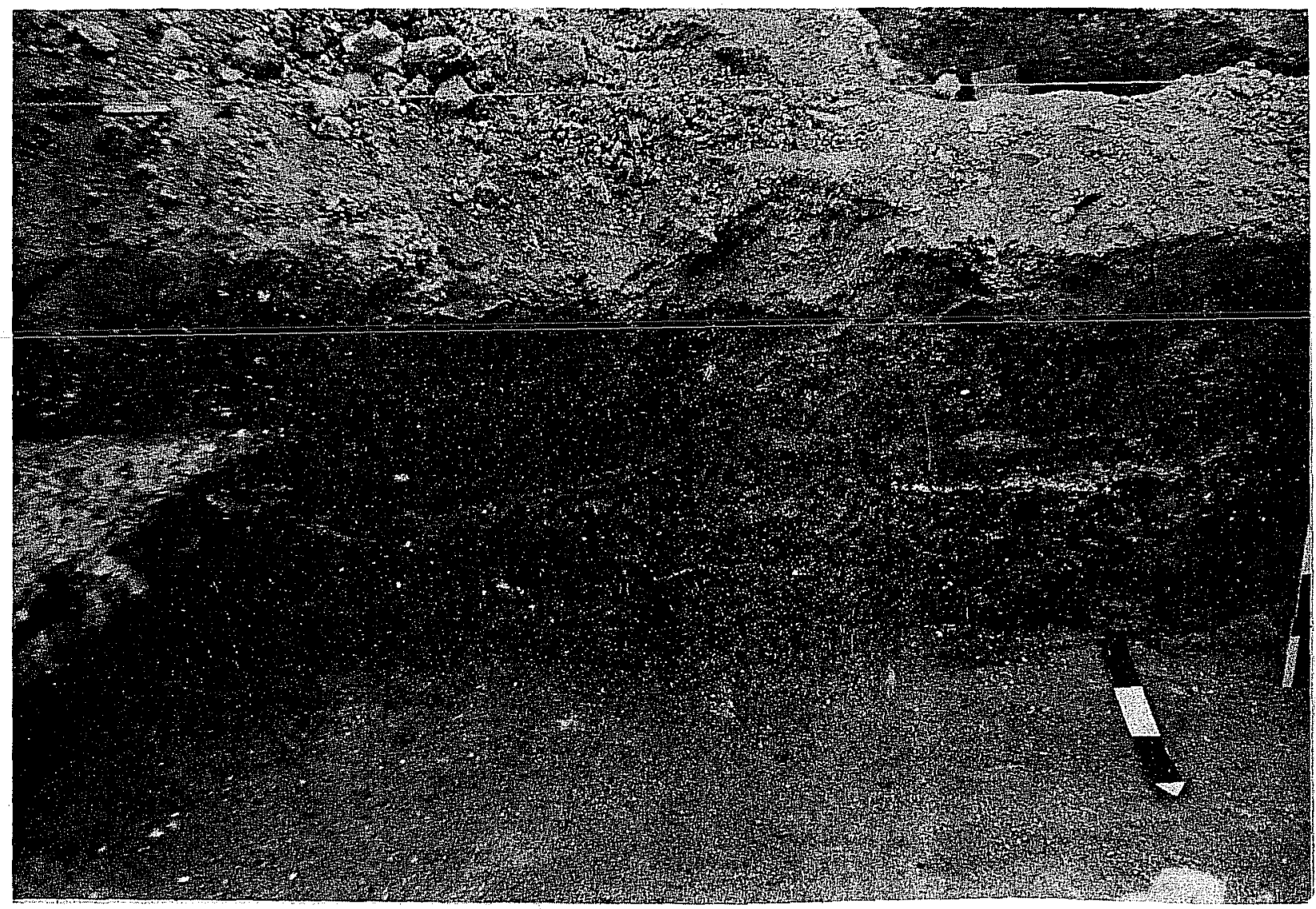

a

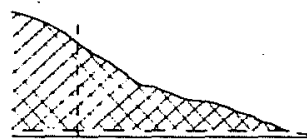

SOUTH PROFILE

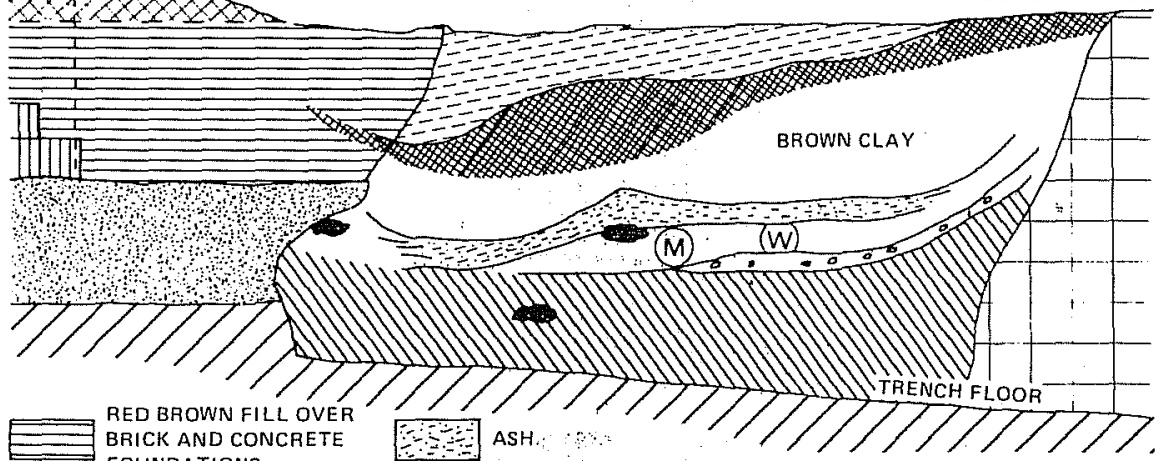
BRICK AND CONCRETE
FOUNDATIONS

IIIIIII BRICK $\because 0$ CALICHE

Th concrete

$E=-3$ ASH, RUBBLE, AND BRICK $\triangle 111 \mathrm{~J}$ GREY-BROWN CLAY

CHARCOALAND ASH

0

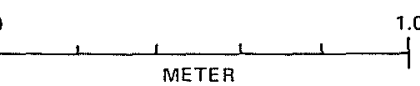

: DARK BROWN EARTH

$\because$ BACK-DIRT PILE

(M) MAJOLICA SHERD

(W) WHEEL-TURNED,

UNGLAZED SHERD

b

Figure 4. South Wall of Construction Trench. 
disturbance of the area and the limited examination made of this feature, it is impossible to make any detailed deductions about the nature or date of these Tayers.

A very general opinion can be offered, however. It appears that the lowest grey-brown level may have been a silt deposit, and the higher levels seem to be washed in rather than dumped into the feature. This could have been a trash pit, but it is also possible that this ditchlike feature might have been a branch of the Concepcion Acequia, predating any of the structures built on this site. The few artifacts found in a relatively undisturbed context within the possible ditch tend to support a date of about 1790 to 1810 . The possibility that it was part of the acequia system must be kept in mind when future excavations in the La Villita area are undertaken.

To the left of this ditchlike feature can be seen a second major intrusion which cut through al1 the previous deposits. This was the footing trench for a brick store built here between 1928 and 1941. It was dug almost exactly on the line of the east wall of the Casas House. This, of course, destroyed any trace of that house wall here, and made it impossible to determine the precise relationship between the Casas house and the ditchlike feature discussed above.

The brick store was demolished in the 1960s, and the lot was scraped by machinery, removing some upper levels and packing mixed debris from all time periods into a hard top layer across the whole site.

\section{THE EXCAVATIONS}

During March 1977, archaeologists from the Center for Archaeological Research conducted excavations at the Gresser House. The field crew consisted of James E. Ivey and Lynn Highley.

The site had already had some new construction completed when excavations began. This consisted of two large cinderblock wal1s protecting the area from pedestrian traffic along Nueva and South Presa Streets. Still in progress were other works, including a series of trenchings for gas and water pipes. Some of this activity had directly affected the foundation traces to be examined (Fig. 3).

These foundation traces consisted of white patches of caliche and limestone forming localized intrusions at the edges of some of the construction ditches. These were visible at areas $A$ and $B$ as shown on Fig. 3. Further examination revealed more traces at areas $C$ and $D$. It was assumed that there was a Tine of foundation connecting areas $A$ and $C$. Four one-meter test squares were staked out along this suspected line, and excavations were begun.

It was found that the surface consisted of severely mixed and disturbed material which had been compacted into a very solid, tough layer about $5 \mathrm{~cm}$ thick. Below this layer was a dark brown clay with small charcoal fragments. This stratum was later determined to extend to at least $45 \mathrm{~cm}$ below the present surface.

The old wall foundations were cut into this stratum. The foundation consisted of lumps of caliche and soft limestone bonded with white sandy lime mortar. This material had been placed directly into a trench which was cut into the brown clay 
and filling the trench to its edges (Fig. 5). The foundation averaged $45 \mathrm{~cm}$ in width and about $33 \mathrm{~cm}$ in depth below the present surface.

No stratigraphy was visible in any section made across the lines of the foundations, implying that the original surface from which they were dug had been above the present surface, and had been destroyed by later construction and earthmoving.

The foundation remains 1 ying between $A$ and $C$ maintained an essentially straight Tine, but there were several areas where the materials of the foundation varied from that line. These can be seen as major irregularities in the outline of the foundation. Probably the disturbances of the foundation were caused by scraping of the ground by heavy machinery. The two crosscut trenches at $E$ are apparent7y the marks of bulldozer blade or backhoe bucket teeth.

After the excavations of test pits 1 through 4 had revealed the nature of the foundation, subsequent limited examinations were made to find other foundation traces. In area $F$, a portion of caliche construction was found, merging with the stones of the Gresser House on the north. At the same point it was noted that the Gresser House structure seemed to have a joint in its foundation at the line of the west face of the interior north-south wall, implying that the west half of the Gresser House was added to the east half after its initial construction.

The soil south of the new wall along Nueva Street was examined and extensions of the foundations were found at $G$ and $H$. The area at $J$ was then checked and additional foundation traces of the Casas House were found. This was done when the sidewalk along the north side of Nueva Street was removed.

No interior floor surfaces of the Casas House were noted, nor any indication of interior walls.

\section{THE ARTIFACTS}

Below are listed the artifacts recovered from examinations at Gresser House. These are listed by categories and types found in the various testing operations. Also given are references used during the classification and analysis of the collected materials. Select artifacts are shown in Figs. 6 and 7 . The artifacts and their proveniences are listed in Table 1.

Preliminary Investigations

Ceramics

Local Hand-made Ware

1 sherd undecorated; fine tan paste with reddish core; Goliad ware (GiTmore 1974:66).

1 sherd red decorated; red paste with darker core, red painted interior. 

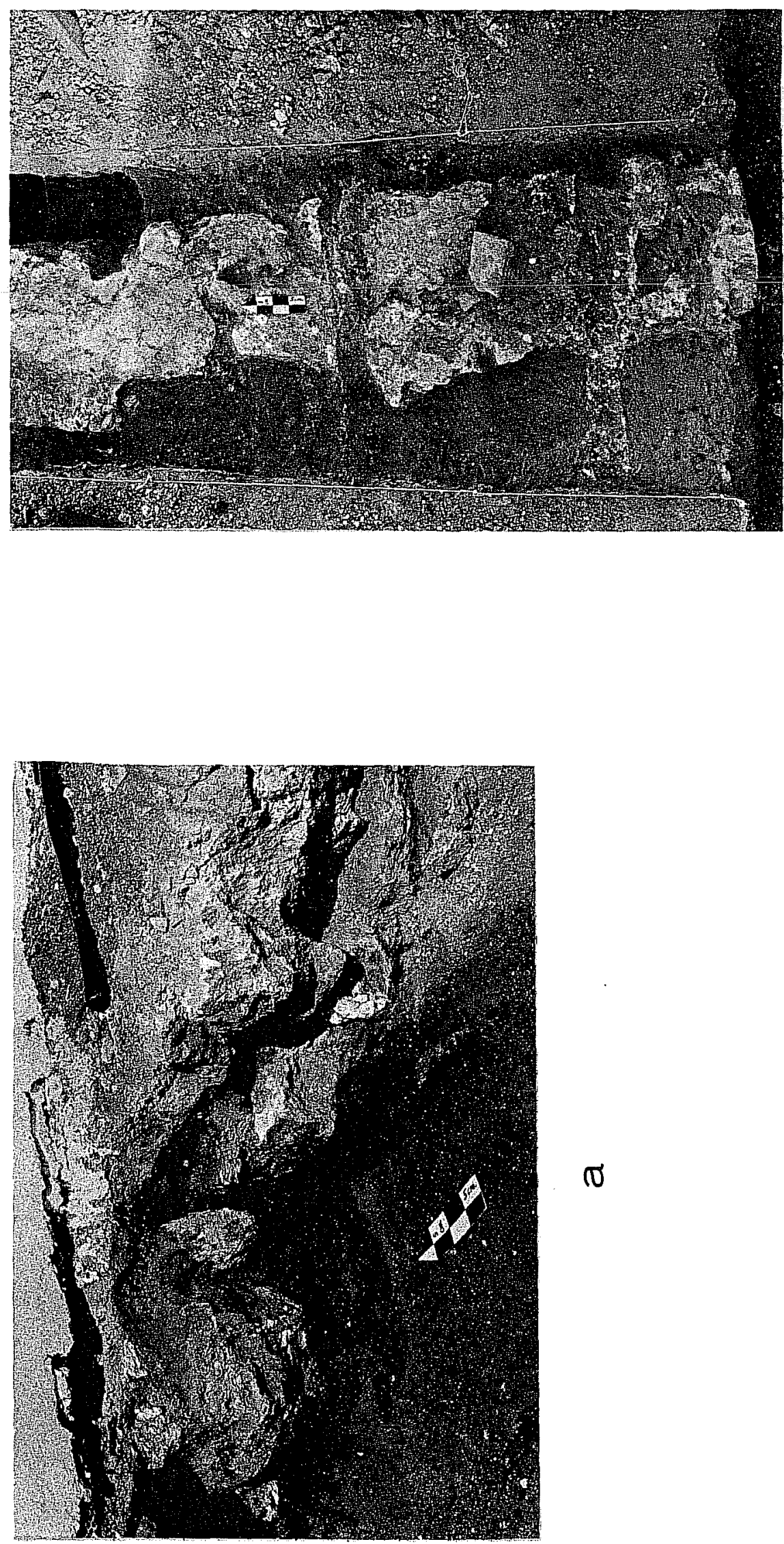
Figure 6. Ceramic Artifacts. a,b, blue she11-edged ware; c, green she11-edged; $d, e$, banded slipware of the type called "mocha": gold, green and brown bands and one band of impressed ropelike pattern above a brown field with white spots and gold and black dendritic patterns; $f$, banded slipware, blue and gold bands and two bands of impressed dots; $g-j$, Majolica: $g$, blue rim stripe over green-white tin glaze, pink paste: possibly Puebla Blue-on-White; $h$, broad green stripe and narrow orange stripe, green floral design over pale yellow green tin glaze, orange pink paste; $i$, two sherds, green rim stripe, orange brown splotches flanking a narrow brown line over green-white tin glaze, pink paste: Aranama or Orange Band Polychrome; $j$, cup base, two narrow parallel brown stripes with small patch of green above, over green-white tin glaze, pink paste; $k$, blue transfer decorated; 1 , white pearlware with a violet lustre floral pattern; $m$, white ironstone, stained gray by fire; $n$, hand painted, blue and yellow floral pattern; 0 , hand painted blue floral pattern; $p$, hand painted, yellow rim stripe, green and yellow-tan floral pattern; q, pipe stem, clear glaze over orange paste; $r$, unglazed wheel thrown, tan paste with darker core; $s$, unglazed, undecorated hand made: Goliad ware; $t$, lead glazed wheel thrown, clear glaze over red brown paste; $u$, lead glazed, tan paste, orange brown glaze, white and black stripes: Decorated Orangeware; $v$, lead glazed; tan paste, orange brown glaze, black decorations: Decorated Orangeware; $w$, carved bone handle to unidentified too $7 x$, ground slate cone, probably slate pencil fragment. 

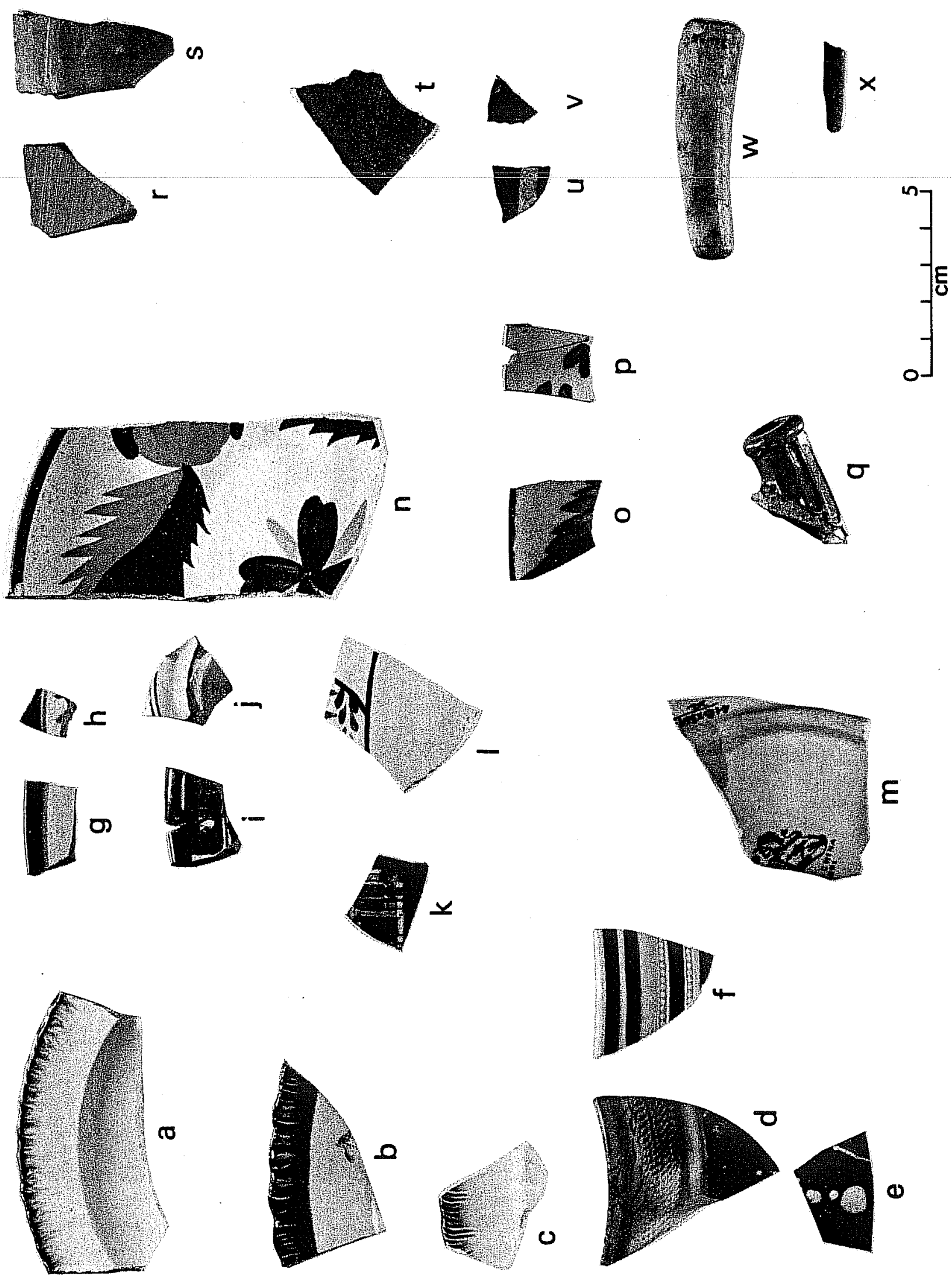

( 

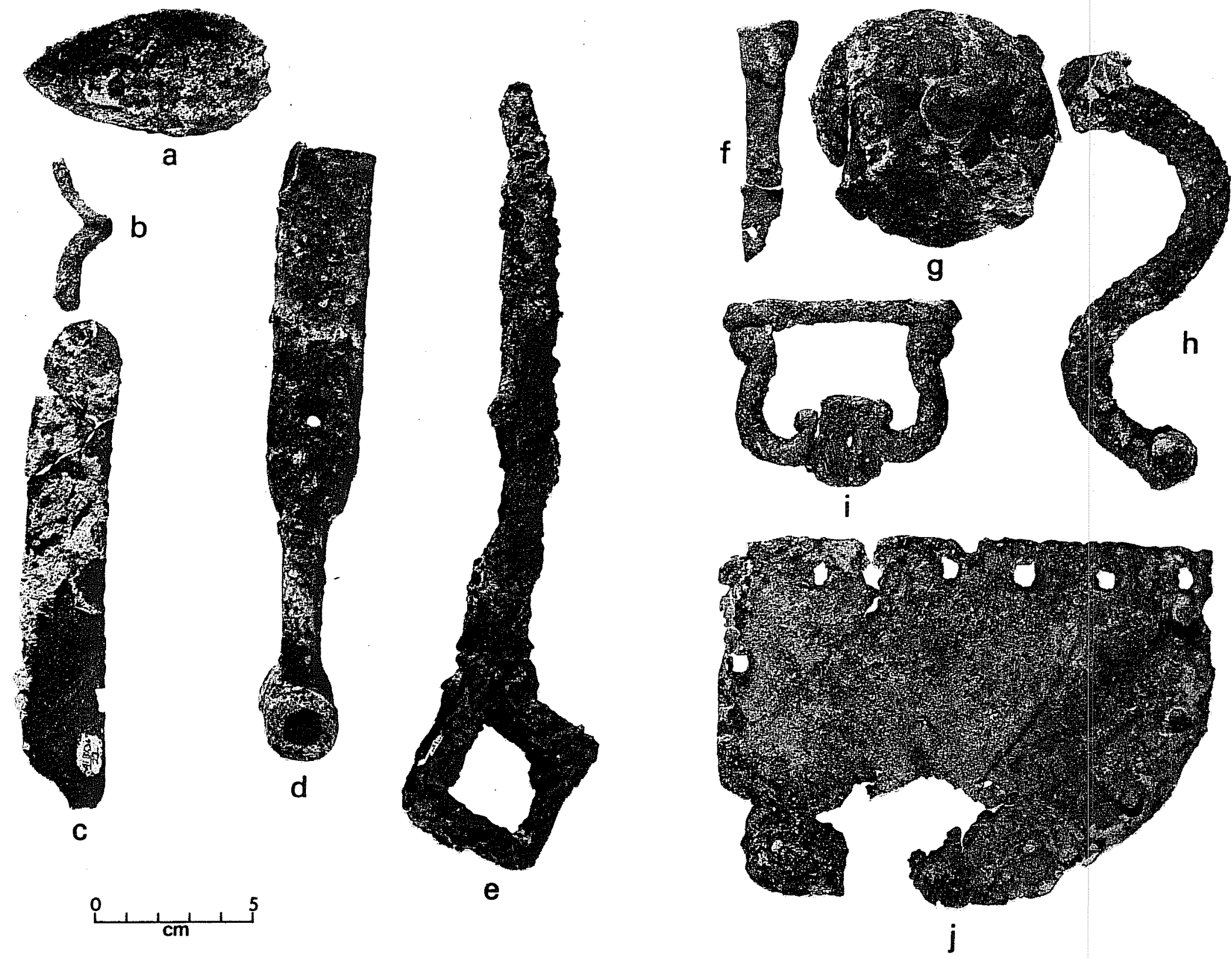

Figure 7. Metal Artifacts. a, iron spoon bow1; b, iron gun part; c, iron knife blade; d, iron machine part; $e$, iron tool; $f$, brass or copper strip with one square nail hole; $g$, coffee grinder, iron; $h$, coffee grinder crank, iron; $i$, brass drawer pul1; $j$, copper sheet, with square nail holes along two sides. 
TABLE 1

GRESSER HOUSE ARTIFACTS AND PROVENIENCES

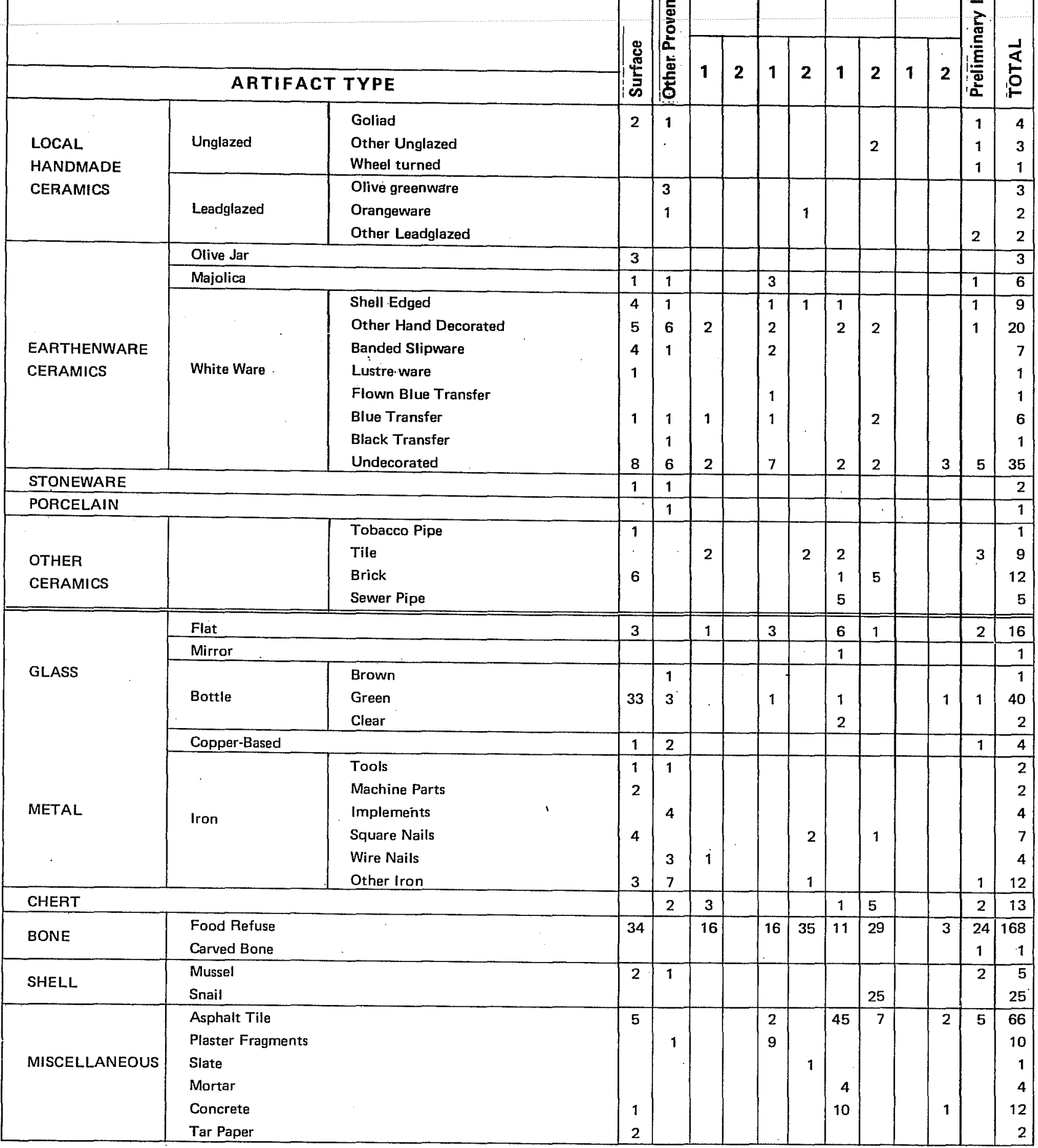


1 sherd unglazed, wheel thrown; tan paste with darker core (Fig. 6,r).

1 sherd lead glazed; fine red brown paste, clear lead glaze. Wheel thrown base of unidentified vessel (Fig. 6,t) (Gilmore 1974:59).

1 sherd lead glazed; rim sherd, fine red paste, yellow lead glaze (Gilmore 1974:58).

\section{Earthenware}

1 sherd tin enameled; pink paste, green-white tin glaze, blue rim stripe. Majolica (Fig. 6,g).

Earthenware; White Paste, Clear Glaze

1 sherd blue hand decorated; molded edge, blue painted. Shell-edged ware (Noel Hume 1970:131; Mallouf et al. 1973:170) (Fig. 6,a).

1 sherd blue hand decorated.

5 sherds undecorated.

other

3 fragments red tile (recent).

Glass

2 fragments clear molded, flat.

1 fragment green bottle.

Metal

1 brass or copper object; probably a drawer handle (Fig. $7, i$ ).

1 fragment iron or steel wire. Two strands twisted together.

Chert

2 fragments.

Bone

24 fragments, predominantiy bovine.

1 carved bone handle to unidentified implement, $5.7 \mathrm{~cm} \times 1.5 \mathrm{~cm}$ (Fig. $6, \mathrm{w}$ ). Shell

2 fragments mussel shel1. 
Miscellaneous

5 fragments asphalt tile.

\section{Test Pit 1; Stratum 1}

\section{Ceramics}

Local Hand-made Ware

1 sherd lead glazed; tan paste, orange brown glaze, mineral inclusions in paste. Decorated Orangeware (Gi1more 1974:59).

Earthenware; White Paste, Clear Glaze

1 sherd blue transfer decorated. Floral print.

2 sherds biue hand decorated.

2 sherds undecorated.

Other

2 fragments red tile. Mexican Brick.

Glass

1 fragment clear molded, flat. Molding is narrow parallel ridges. Green and white layers of paint on both surfaces.

Metal

1 fragment iron--wire nail.

Chert

3 fragments.

Bane

16 fragments; predominantly bovine.

Miscellaneous

7 fragments asphalt tile. 


\section{Test Pit 2; Stratum 1}

Ceramics

Earthenware

2 sherds tin enameled; pink paste, green-white glaze, green rim stripe, orange brown splotches flanking a narrow brown line. Majolica, possibly one of the Aranama Polychrome or Orange Bond Polychrome traditions (Barnes and May 1972:12) (Fig. 6,i).

1 sherd tin enameled; orange pink paste, yellow green glaze, broad green stripe and narrow orange stripe, green floral design. Majolica (Fig. 6,h).

Earthenware; White Paste, Clear Glaze

2 sherds banded slipware; annular broad black stripes. Mocha (Noel Hume 1970:131; Mallouf et al. 1973:170).

2 sherds hand decorated; yellow painted stripe, green and yellow floral design (Fig. $6, p$ ).

1 sherd blue transfer decorated. Flown Blue (Mallouf at al. 1973:167; GiTmore 1974:44).

I sherd blue transfer decorated. Floral print.

1 sherd blue hand decorated; molded shell edge, blue painted. Shell Edged (Noel Hume 1970:131; Ma17ouf et al. 1973:170).

5 sherds undecorated.

1 cup base; undecorated.

1 cup handle; probably from the same vessel as the two hand-decorated yellow and green floral sherds above.

Glass

3 fragments clear molded, flat.

I fragment green bottle.

Bone

16 fragments, predominantly bovine.

Miscellaneous

2 fragments asphalt tile.

9 plaster fragments; some have a blue painted surface overpainted with white. 
Test Pit 2; Stratum 2

Ceramics

Local Hand-made Ware

1 sherd lead glazed; tan paste, orange brown glaze. Minerai inclusions in paste. Black decorations. Decorated Orangeware (Gi1more 1974:59) $($ Fig. $6, v)$.

Earthenware; White Paste, Clear Glaze

1 sherd green hand decorated; molded shell edge, green painted. Shel1 Edged (Noel Hume 1970:131; Mallouf et al. 1973:170). (Fig. 6, C).

5 sherds undecorated.

Other

2 sherds red brick tile. Mexican Brick.

Metal

2 fragments iron--square nai1.

1 unidentified iron object--possibly a gun part (Fig. $7, b)$.

Bone

35 fragments, predominantly bovine.

Miscellaneous

1 fragment of slate roughly ground into a narrow cone, $2 \mathrm{~cm}$ in length, $3 \mathrm{~mm}$ in width. Probably a portion of a slate pencil (Fig. $6, x$ ).

\section{Test Pit 3; Stratum 1}

Ceramics

Earthenware; White Paste, Clear Glaze

1 sherd blue hand decorated; molded shell edge, blue painted. Shel1 Edged (Noel Hume 1970:131; Mallouf et al. 1973:170).

2 sherds blue hand decorated.

2 sherds undecorated.

Other

5 fragments glazed sewer pipe. 
2 fragments red brick tile. Mexican Brick.

1 yellow brick.

Glass

6 fragments clear molded, flat.

2 fragments clear bottle.

1 fragment green bottle. Lip fragments.

1 fragment mirror.

Chert

1 fragment.

Bone

11 fragments, predominantly bovine.

Miscellaneous

45 fragments, asphalt tile.

4 fragments mortar.

10 fragments concrete.

Test Pit 3; Stratum 2

Ceramic

Local Hand-made Ware

2 sherds unglazed, undecorated; coarse tan paste.

Earthenware; White Paste, Clear Glaze

1 sherd blue hand decorated.

1 sherd blue transfer decorated.

2 sherds undecorated.

Other

5 fragments brick.

Glass

1 fragment clear molded, flat. 
Metal

1 fragment iron--square nai1.

Chert

5 fragments.

Bone

29 fragments, predominantly bovine.

Shell

24 snail shells.

1 fragment mussel shell.

Miscellaneous

7 fragments asphalt floor tile.

Test Pit 4; Stratum 2

Ceramics

Earthenware; White Paste, Clear Glaze

3 sherds undecorated.

Glass.

1 fragment green bottle.

Bone

3 fragments, predominantiy bovine.

Miscellaneous

1 fragment concrete.

2 fragments asphalt tile.

Artifacts from Construction Trenches

Ceramics

Stoneware

1 cup base fragment; tan grey paste, trace of salt glaze. 
Locai Hand-made Ware

1 sherd lead glazed; tan paste, orange brown glaze, hand decorated in white and black stripes. Decorated Orangeware (Gilmore 1974:59) (Fig. 6,u).

2 sherds lead glazed; tan paste, green brown glaze. 01ive-Green Sandy Paste Ware (Gilmore 1974:56).

1 sherd lead glazed; red brown paste, green glaze. 01ive-Green Sandy Paste Ware (Gilmore 1974:56).

1 sherd undecorated; brown paste, unglazed. Goliad Ware (Gilmore 1974:66).

Earthenware

1 sherd tin enameled; red brown paste, tin enameled pale green glaze. Majolica.

Earthenware; White Paste, Clear GTaze

1 sherd blue hand decorated; molded shell edge, blue painted. Shell Edged (Noel Hume 1970:131; Ma17ouf et al. 1973:170) (Fig. 6,b).

1 sherd banded slipware; annular rings of blue and brown. Trace of spout--fragment is from pitcher. Mocha (Noel Hume 1970:131; Mallouf et al. 1973:170).

2 sherds hand decorated; blue and yellow floral hand-painted decoration.

4 sherds blue hand decorated; floral design.

1 sherd blue transfer decorated (Fig. 6,k).

1 sherd black transfer decorated; black floral print (Mallouf et al. 1973:167).

1 sherd undecorated ironstone; partial maker's mark: right half, a unicorn rampant supporting a square shield over a scroll; under this are the letters "CHINA/... RDS" (Fig. 6,m).

5 sherds undecorated.

Porcelain

1 sherd undecorated.

Glass

3 fragments green bottle.

1 fragment brown bottle. 
Metal

2 fragments copper or brass--unidentified. One piece has a small (1 mm). square hole through it (Fig. $7, f$ ).

7 fragments iron--unidentified.

1 iron tool-- $19 \mathrm{~cm}$ handle, square-eyed end, $3.1 \mathrm{~cm} \times 3.3 \mathrm{~cm}$ internal dimensions.- Unidentified (Fig. $7, \mathrm{e})$.

3 wire nails.

1 fragment iron--bowl of large spoon (Fig. $7, a$ ).

3 fragments iron--knife blade, rounded nose, $15.3 \mathrm{~cm} \times 2.5 \mathrm{~cm}$. Table or butter knife (Fig. $7, \mathrm{C}$ ).

Chert

2 fragments.

Bane

79 fragments, predominant7y bovine.

Shell

1 fragment mussel she 11.

Miscellaneous

1 fragment plaster.

A number of fragments of what appears to be wallpaper.

Artifacts of Unknown Provenience

Ceramics

Stoneware

1 doorknob.

Local Hand-made Ware

2 sherds unglazed; undecorated. Goliad Ware (Gilmore 1974:66) (Fig. 6,s).

Earthenware

3 sherds brown paste, heavy green lead glaze. OTive Jar (Gi Tmore 1974:61; Goggin 1964:272). 
1 fragment pipe stem; orange brown paste, clear glaze, raised ridge pattern (Noel Hume 1970:303) (Fig. 6,q).

1 sherd tin enameled; cup base, pink paste, green-white tin enameled glaze, two narrow parallel brown stripes on body, with small patch of green paint above. Similar to two sherds with orange brown paint from Test Pit 2, Stratum 1 and possibly from same vessel. Majolica (Fig. $6, j$ ).

Earthenware; White Paste, Clear Glaze

1 sherd blue transfer decorated.

3 sherds blue hand decorated (Fig. 6,0).

2 sherds hand decorated; blue and yellow floral design. Part of same vessel as sherds found in construction trenches (Fig. $6, n$ ),

3 sherds blue hand decorated; molded edge, blue painted. She11-Edged Ware (Noe1 Hume 1970:131; Mallouf et al. 1973:170).

1 sherd green hand decorated; molded edge, green painted. She17-Edged Ware.

4 sherds banded stipware

2 sherds: 1 rim, 1 body; gold, green and brown annular bands, one band of impressed ropelike pattern, above a brown field with white spots and gold and black swirls (Fig. 6,d,e).

1 sherd: Tight and dark blue annular bands.

1 sherd: rim; black, b7ue and gold bands, and two bands of impressed dots (Fig. 6,f).

1 sherd lustre decorated; metallic violet floral design under glaze. Lustre ware (Mankowitz and Haggar n.d.:137) (Fig. 6,1).

8 sherds undecorated; one is a cup or mug handle.

Other

2 fragments red brick.

2 fragments yellow brick.

2 red brick.

Glass

3 fragments ciear, flat. 
1 fragment very dark green bottle; base.

32 fragments green bottle--all from same vessel.

Metal

3 square naits.

1 fragment square naj1.

1 iron strip--22 cm $\times 2 \mathrm{~cm} \times 6 \mathrm{~mm}$. Unidentified.

1 iron tool--flat handle $19 \mathrm{~cm} \times 2.5 \mathrm{~cm}$, attached to the side of a metal cylinder $5 \mathrm{~cm} \times 1.5 \mathrm{~cm}$ with an unthreaded hole $.5 \mathrm{~cm}$ in diameter. Unidentified machine part (Fig. 7,d).

1 square spike with a flat eye, $13 \mathrm{~cm}$ in length.

1 cast iron plate, $20 \mathrm{~cm} \times 11.5 \mathrm{~cm}$; possible stove part.

1 rectangular sheet of copper, $15.5 \mathrm{~cm} \times 12 \mathrm{~cm}$, 1ess than $1 \mathrm{~mm}$ in thickness, with square holes along two edges and copper rivets along remaining two sides (Fig. $7, j$ ).

1 iron handle--coffee grinder handle (Fig. 7, h).

1 iron grinder--coffee grinder (Fig. $7, g$ ).

Bone

34 fragments, predominantly bovine.

Shell

2 fragments mussel she11.

Miscellaneous

1 fragment concrete.

2 large fragments tar paper.

5 fragments asphalt tile.

\section{ARTIFACT DATING}

Of the artifacts listed above, many are as yet of uncertain date or are of such a nature as to be generally undatable. Some, however, do have periods associated with them and these will be briefly treated below. 
Pottery

Blue transfer-decorated earthenware (Fig. 6,k) most likely dates from between 1820 and 1830, but could range from 1795 to the present. Black transfer prints usual1y indicate a date of post-1830 (Mallouf et al. 1973:167): B Bue handdecorated earthenware (Fig. $6, n, 0$ ) could date from 1795 to the present.

She11-edged wares (Fig. 6,a-c) date from as early as 1795, and are considered to indicate a date, in Texas, of earlier than 1850 (Mallouf et al. 1973:170); they were made from 1780 to about 1830 (Fox et al. 1976:58; Noel Hume 1970:131). Some of the blue hand-decorated sherds mentioned in the previous paragraph are probabiy from shell-edged plates and would, therefore, date well before 1850 .

Banded slipware' and "Mocha" ware (Fig. 6,d-f) were made from about 1787 to as late as 1903, but are considered to indicate a date in Texas of from 1800 to 1850 (Noel Hume 170:131; Mal1ouf et al. 1973:167-170).

Majolica (Fig. 6,g-j) dates range from the 17th century to the late 19th century, and accurate dating depends on accurate identification, which is frequently difficult when dealing with small sherds. The Aranama traditions (Fig. $6, i$ ) date from about 1790 to 1830 (Barnes and May 1972:12) but there is no way to be certain of the attribution of these sherds to this tradition.

\section{Other Artifacts}

A very dark green bottle base (not illustrated) is quite similar to one of the Bertrand Bottle types set up by Ronald Switzer (Switzer 1974:17) and would, therefore, date to about 1860 .

An examination of Table 1 shows that early and late materials are distributed over the site in no discernible order. Stratum 2 in each test pit, which would have had the most representative collection of pre-Casas House artifacts, was rarely examined any deeper than necessary to expose the üper surface of the foundation, and so still contained material forced into it from the refuse and debris of stratum 1.

Those artifacts from proveniences other than test pits are al1 from the examination of the footing trenches of the Casas and Gresser Houses in the area of the south wall of the Gresser House and, therefore, probably include material from the period of construction of both the Casas House and the Gresser House. In general, these artifacts show a date range of about 1800-1850, with a few from periods after 1850 .

In general, the artifactual evidence shows that the site has been subjected to severe disturbance, but leaves little doubt that its earliest occupation dates to at least $1800-1820$.

\section{CONCLUSIONS}

The examination of the foundations uncovered during the excavations at Gresser House (Fig. 3) clearly indicates that they are those of the small structure seen 
on the south side of the Gresser House in a photograph taken in 1928 (Fig. 8,a). This is confirmed by a later photograph taken during recent renovation of the Gresser House (Fig. 8,b). This picture shows the south wall of the Gresser House before it was replastered, and the imprint of the adjacent structure seen in the 1928 photograph is clearly visible.

Artifacts found in association with the foundations show that this structure was probably built in about the first quarter of the 19th century (1800-1825). We know from the archival records that the "Casas House" existed on the lot from about 1800-1825 until after 1928 .

This means that the building had to have been on the lot in 1841 . It is, therefore, very likely to have been the house mentioned in the Casas Inventory and Partition of that year. This is described as "a house consisting of two rooms on the front [of the lot] and a deteriorated kitchen, with its walls and roof of wood and straw" (BCDR, J1:458).

We can go into somewhat more detail than this. In the 1928 photograph (Fig. 8,a), the Casas House can be seen to have a stone footing somewhat wider than the walls. It is possible that the walls above the foundation were of wooden construction rather than of stone. In a 1939 newspaper article about La Villita we find a detailed description of what was probably the Casas House: "It was built of cedar posts, erected upright and held together with rawhide. The interstices were filled with mud, which was used as a stucco and the house was kept in a whitewashed condition... No nails were used in building the framework of this house, the rafters for the roof being cedar posts tied together with rawhide, and the house originally had a thatched roof" (San Antonio Express, December 31,1939$)$. This use of wood tied with rawhide is probably the construction technique called chamacuero in early deeds of San Antonio (Fox 1977:3, 4). The term apparently came from chamada, brushwood or kindling, and cuero, hide, and is probably virtually interchangeable with the term palisado, a construction of vertical posts usually chinked with mud.

Our bits and pieces of evidence from various sources, archaeological, historical and photographic, have given us an idea of the appearance and construction of the Casas House.

The land on which the Casas House stood was probably that granted to Miguel Buentel10 in 1818. Buentello himself gives us some important information about the history of the site in his petition to Antonio Martinez for the land: "even while your predecessor Governor Salcedo was Tiving [Manuel De Salcedo was killed in Apri1, 1813]. . . I maintained my dwelling on a site in the Villita" (BCA, LGS:92). The remainder of the petition makes it fairly clear that Buente110 was asking to be granted title to the land on which he already was living. This means that a house stood on the Buente110 (later the Casas) lot at least as early as 1813. It is 1ikely, however, that this house was severely damaged or destroyed by the flood of 1819, especially considering that Buentel10's neighbors on the north and south lost their houses in the same flood.

Casas, however, was not daunted by this, and sometime after 1819 built a house of his own, possibly reusing Buente170's foundation. Maria Casas sold the house to Louis Gresser in 1861, and soon thereafter Gresser built a stone addition onto the north side. This is apparent from the nature of the surface visible in Figures 3 and 5 in the area where the stone wall was covered by the 
Casas House. It is obviously unsurfaced and formed an interface between the then standing Casas House wall and the new stone wall of the northern rooms. The "Gresser House" addition was typical of the cut limestone houses built in La Villita in the 1860s and 1870s after the arrival of the German settlers in the town.

The standing house, which could be called the Gresser-Casas House (instead of Gresser-Hays House), was handed down through its series of owners; the Casas portion became a store which had a false front roof added, and then in the late 1920 s probably burned. The 1928 photograph shows what could be burn damage on the house. This is suggested by black streaks on the walls, the false front roof gone except for a few fragments on the south edge, and the rest of the roof missing in back. The 1939 Express article mentioned above states that the structure described "burned down a few years ago."

Sometime after 1928 and before 1941 the fire-damaged Casas House was torn down and a brick store was built in its place. This in turn was torn down in the 1960 s, when the many construction projects for Hemisfair were going on. During that demolition, the area of the Casas House was apparently bulldozed. This removed the top several inches of earth from the site, which probably included the original floor surfaces of the Casas House, and destroyed a great deal of information about the way of life of an average family in pre-Revolution San Antonio. Only by chance was sufficient information left in the earth to give the clues needed to permit this reconstruction of the Casas House structure and history. Even so, a great deal more was lost than has been saved.

Jack Hays and the Gresser House

There is a strong tradition which links Colonel John Coffee Hays of the Texas Rangers with the Gresser House. Since it is likely that the structure presently called the "Gresser House" was indeed built in the 1860s by Louis Gresser, it would be better to say that Hays is linked with the now-destroyed house of Jose and Maria Casas. This tradition is stated explicitly in Rena Maverick Green's (1952:102[n]1) biography of Samuel Maverick: "Some buildings and the original fence of Hays' San Antonio house still stand at the northwest corner of Presa and Nueva Streets."

In James Kimmins Greer's (1952:161) book, Colonel Jack Hays, he gives a somewhat less explicit site for Hays' house: "... in San Antonio's two hundred block on South Presa Street....," and adds that the house had been constructed beginning in Tate 1846 or early 1847, was of two stories and presumably was finished by the time of Hays' marriage to Susan Calvert on Apri1 29, 1847.

How much of this tradition can be supported by the historical record is uncertain. The deed records of Bexar County show Hays as having purchased a number of tracts of 1 and between the late 1830s and the late 1840s, but of these recorded purchases, only one was in San Antonio proper (Fig. 2). It was a parcel of land containing most of the central lots of new city block 134, which is bounded on the north by Nueva Street, on the east by South Presa Street, and on the west by South Saint Mary's Street (BCDR, GI:369). For at least some portion of its existence, this block as it faces east was the 200 block of South Presa Street (Varga 1967:3). 


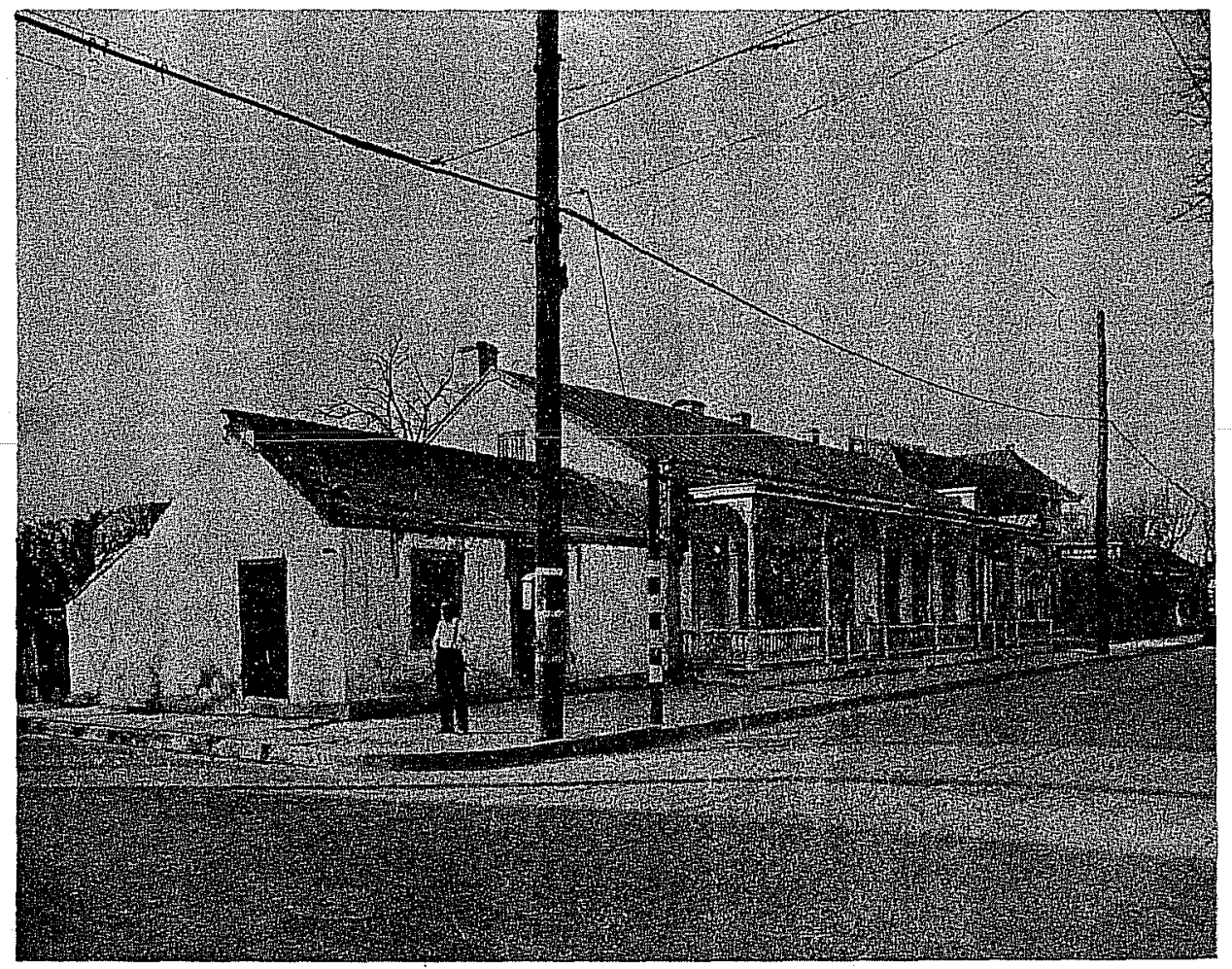

a

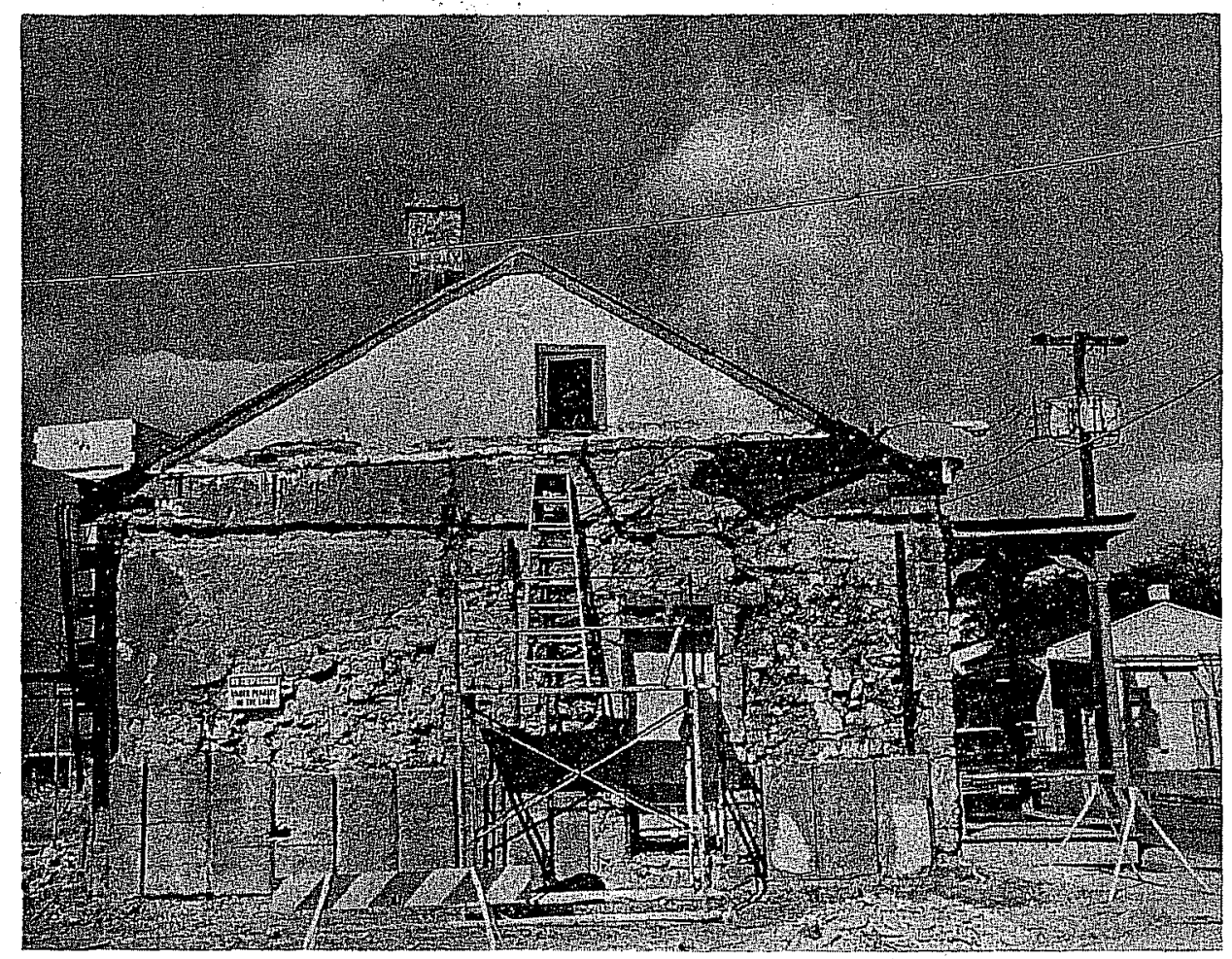

b

Figure 8. The Gresser House. a, Photograph taken in 1928 when the Casas House was still standing. Note what appears to be fire damage to the roof and walls; $b$, South wall of Gresser House during renovation. The outline of the Casas House roof is visible on the wall plaster. 
Hays, however, purchased the lot in 1848, not at some earlier time. There are no records available to indicate whether fiays built on the lot, but is is stated that a house and other structures were standing on it when it was sold to him; "...the northernmost portion running from the Street, Presa, to the acequia fronting 30 varas on the Street...together with the dwelling house and outhouses on said portion..."(BCDR, GT:369, 24 August 1848). According to other statements in the same document, there were apparently no other houses on this tract.

Hays left Texas for California in 1849 (Green 1952:102[n]1; Webb 1952, 1:789). On Apri1 24, 1853, he assigned power of attorney to his father-in-1aw, Jeremiah S. Calvert, who was to sell Hays' remaining Texas property for him (BCDR, L2:304). Specifically mentioned in this document is permission for Calvert to sell what Hays calls "my house and lot in the city of San Antonio." This makes it quite clear that Hays lived on land which he himself owned, not in a rental or leased house on some other property, although such an arrangement may have been in effect temporarily between his wedding in April 1847 and the purchase of his lot in August 1848.

The tract was eventually divided into thirds and sold to members of the Calvert family (BCDR, 48:249,251; 11:513). At the time of these transfers in Apri1 and October 1877, there was still mention of one house on the lot, in the upper one-third, and the tract was said to be "known as the Hays property" (BCDR, 48:251).

It is reasonable to conclude that this house on the upper one-third of the Hays property, on NCB134, must have been the home in which he and Susan Calvert Hays lived in 1848 and 1849 before Hays left for California. That house was torn down some time in the past few years and a parking lot is now in its place.

There are no solid facts in the records and documents so far examined supporting any connection between Hays and the Casas House. Certainily there was no reason for Hays and his wife to live on some portion of Maria Concepcion Gonzales y Casas $^{1}$ lot when he had a large lot and a house of his own within a few hundred feet. There is no doubt that Maria Casas owned her lot, described as "the residence of Mrs. Casas," until 1861 (BCDR, S2:51-52). However, it is possible that some future evidence may be found to change the picture presented here, and one explanation of the traditions linking Hays to the Casas-Gresser lot was, as suggested above, that Hays and his wife rented a house on that lot until the purchase of Hays' house and lot in 1848.

In conclusion, the historic house located on Nueva and South Presa Streets, previously called the Gresser-Hays House, could more properly be called simply the Gresser House, since it was built by Louis Gresser in the 1860s. There is no clear evidence that Jack Hays ever lived at this location, unless it was at the Casas House. The Gresser House was built later than, and adjacent to, the older Casas House, which has long been destroyed.

\section{RECOMMENDATIONS}

Any further disturbance of the earth around the standing structure of the Gresser House should be preceded by investigations by an archaeologist. Some possible things to look for are: a) the original kitchen, traces of which may survive 
immediately west of the Casas House foundations; b) the Buentel10 House foundations, which may still exist somewhere on the lot and c) traces of the other adobe structures indicated as being on the lot in the Sandborn books (Sandborn 1912-1947, 4:342).

In addition to these specific points, the possibility that the "ditchlike" feature examined in the preliminary investigations by Fox is an old portion or lateral of the Concepcion Acequia. It should be investigated in any future area disturbance north or south of the Gresser and Casas Houses. 


\section{REFERENCES CITED}

Barnes, M. R. and R. V. May

1972 Mexican Majolica in Northern New Spain. Pacific Coast Archaeological Society Occasional Papers 2.

Buckley, E. C.

1911 The Aguayo Expedition into Texas and Louisiana, 1719-1722. Quarterly of the Texas State Historical Association XV(1):1-65.

Fox, A. A., F. A. Bàss, Jr. and T. R. Hester

1976 The Archaeology and History of Alamo Plaza. Center for Archaeological Research, The University of Texas at San Antonio. Archaeological Survey Report 16.

Gilmore, $K$.

1974 Mission Rosario Archeological Investigations 1973. Archeological Report 14:1. Texas Parks and Wildlife Department, Parks Division, Historic Sites and Restoration Branch.

Goggin, J. M.

1964. The Spanish 01ive Jar. Indian and Spanish Selected Writings. University of Miami Press, Coral Gables.

Green, R. M., Editor

1952 Samuel Maverick, Texan: 1803-1870, A Collection of Letters, Journal and Memoirs. Privately printed. San Antonio.

Greer, J. K.

1952 Colonel Jack Hays. E. P. Dutton and Company, Inc., New York. Mallouf, R. J., D. E. Fox and A. K. Briggs

1973 An Assessment of the Cultural Resources of Palmetto Bend Reservoir, Jackson County, Texas. Texas Historical Commission and Texas Water Board. Archeological Survey Report 11.

Mankowitz, W. and R. G. Haggar

n.d. The Concise Encyclopedia of English Pottery and Porcelain. Hawthorn Books, Inc., New York.

Noel Hume, I.

1970 A guide to Artifacts of Colonial America. A7fred A. Knopf, New York. 
Sanborn Map Company

1912- Insurance Maps of San Antonio, Texas 1-6. Sanborn Map Company, 1947 New York.

Switzer, R. R.

1974 The Bertrand Bottles, A Study of 19th-Century Glass and Ceramic Containers. National Park Service. U.S. Department of the Interior, Washington.

Varga, J.

1967 Jack Hays Had a House. Manuscript on file at San Antonio Conservation Society.

Webb, W. P., Editor

1952 The Handbook of Texas, Vol. 2. Texas State Historical Association, Austin.

\section{NEWSPAPERS}

San Antonio Express. December 31, 1939.

\section{DOCUMENTS CONSULTED}

Bexar Archives

Bexar County Archives, Land Grants and Sales

Bexar County Courthouse Records: Spanish Records, Deed Records, Probate Minutes 